\title{
Orta Anadolu'nun Doğusunda Bir Topluluk: Kayalıpınar İnsanları
}

* Sorumlu Yazar / Corresponding Author: İbrahim SARI Sivas / TÜRKIYE E-posta: paleoibrahim@gmail.com

\author{
İbrahim Sarı ${ }^{\prime *}$, Mehmet Sağır ${ }^{2} \odot$ \\ 'Dr. | Bağımsız araştırmacı, Sivas / TÜRKiYE \\ ${ }^{2}$ Prof. Dr. | Ankara Üniversitesi, Dil ve Tarih - Coğrafya Fakültesi, Antropoloji Bölümü, Sıhhiye - Ankara / TÜRKiYE
}

Alındı/Received: 16 Nisan / April 2020 Düzeltildi/Revised: 14 Mayıs / May 2020 Kabul/Accepted: 4 Haziran / June 2020 Yayımlandı/Published: 29 Haziran / June 2020

Öz

$\mathrm{Bu}$ çalışmada, Sivas İli Yıldızeli İlçesi'nde yer alan ve HellenistikErken Bizans dönemine tarihlendirilen Kayalıpınar topluluğunun nüfus dinamikleri incelenmiştir. Çalışmanın amacı Kayalıpınar topluluğunun demografik özelliklerinin ortaya çıkarılması ve aynı döneme ait eski Anadolu toplulukları ile olan benzerliklerinin ve/veya farklılıklarının tespit edilmesidir. Farklı mezarlardan açı̆̆a çıkarılan toplam 211 bireye ait iskelet kalıntısı çalışmanın materyallerini oluşturmaktadır. Toplulukta kadın bireylerin sayısı erkek bireylerden fazladır. Bebek ve çocuk ölümlülüğü $(\% 18,48)$ birçok topluma göre oldukça düşüktür. Erişkinler arasında, orta erişkin yaş grubundaki birey sayısı her iki cinsiyette de daha fazladır. Ölümler kadınlarda 20-25 yaş, erkeklerde ise 35-40 yaş aralığında yoğunlaşmıştır. Yaşamın ilk beş yılı içerisindeki bireyler için hesaplanan yaşam beklentisi 28,24 yıldır. Elde edilen sonuçlar, bu eski insan topluluğunun nüfus yapısını ve profilini aydınlatması bakımından dikkat çekici bilgiler sağlamıştır.

Anahtar Sözcükler: Kayalıpınar, paleodemografi, biyoarkeoloji, Sivas

\section{Giriş}

Sivas İli ve çevresi tarihi itibariyle farklı uygarlıkların idaresi altında kalmış ve sosyal, ekonomik, jeolojik konumu ve kültürel zenginliklerine bağhı olarak kimi zaman bir cazibe merkezi kimi zaman ise yaşamın durma noktasina geldiği bir yer olmuştur. Neolitik ve Kalkolitik dönem yerleşmelerinin bulunduğu Sivas İli, Hitit, Roma, Selçuklu ve Osmanlı dönemlerine tanıklık etmiş, savaşlar, politik girişimler ve nüfus hareketlerinden fazlasıyla etkilenmiştir (Ökmen, 2001; Akbulut, 2009). 13. yüzyllda ticaret merkezi konumunda olan il, farklı yerlerden gelen birçok tüccarın uğradığı bir yer özelliğini taşı (Cahen, 2000). Yakın tarihine bakıldığında ise Sivas İli, Milli Mücadele’nin başlangıcı ve sonrasında burada alınan kararları itibariyle Türkiye Cumhuriyeti Devleti'nin kurulmasinda önemli bir merkez olma görevini üstlenmiștir (Ökmen, 2001; Akbulut, 2009).

Sivas İli'ndeki arkeolojik kazı çalışmaları sınırlı sayıdadır. Çalışmalar ağırlık olarak yüzey araştırması

\section{A Population in the East of Central Anatolia: Kayalıpınar People}

Abstract

In this study, population dynamics of Hellenistic-Early Byzantine Kayahponar people located in the Yuldreli district of Sivas were examined. The aim of the study is to uncover the demographic characteristics of the Kayalipinar individuals and to determine the similarities and/or differences with the ancient Anatolian societies from the same period. The skeletal remains of a total of 211 individuals uncovered from different graves constitute the materials of the study. The number of females in the population is more than males. Infant and child mortality (18.48\%) is quite low compared to many other populations. Among adults, the number of individuals in the middle adult age group is higher in both sex. Deaths are concentrated between 20-25 years for females and 35-40 years for males. Life expectancy calculated for individuals within the first five years of life is 28.24 years. The obtained results provided noteworthy data in terms of shedding light to the population structure and profile of this ancient human population.

Key Words: Kayahpinar, paleodemography, bioarchaeology, Sivas

şeklindedir. Sivas İli Yıldızeli İlçesi'ne bağlı Kayalıpınar Köyü'nde bulunan Kayalıpınar yerleşim alanı da yüzey araştırmaları sonucunda tespit edilmiştir (Ökse, 1994; 1999). 1999 y1lında Hitit çivi yazılı tabletin yüzeyde bulunması nedeniyle arkeolojik kazı çalışmalarının yapılması gerekliliği ortaya çıkmıştır. Yapılan çalışmalar neticesinde Asur Ticaret Kolonileri Çağı (Karum Devri), Orta Hitit Devri, Hitit Büyük İmparatorluk Devri ve Hellenistik-Erken Bizans ile ilişkili izlere ulaşılmıştır (Müller-Karpe ve Müller-Karpe, 2006, 2012).

Antropolojik incelemelerin çalışma materyallerini insan iskelet kalıntıları oluşturur. Kazı çalışmalarıyla ele geçen kültür öğelerinin ve bu öğelerin üreticisi olan insan topluluklarının yaşam biçimlerinin yeniden hayat bulmasinda paleodemografi üzerinde durulması gereken bir terimdir (Büyükkarakaya, 2017). Bu terim insan iskeletlerinden yararlanarak topluluk demografisi ile ilişkili verilere ulaşmayı hedefleyen (Hoppa, 2002); doğum, ölüm ve göçle ilişkili oranlar ve düzeyleri, 
bunların populasyon büyüklüğü (ya da azalışı), yoğunluğu ve yaş ve cinsiyet yapılarını oluşturmak için nasıl etkileşim halinde oldukları, bu oran ve düzeylerin zaman ve mekân bağlamında nasıl değiştikleri, böyle bir çeşitliliğe yol açan etken ve insan yaşamındaki sonuçları gibi konuları irdeleyen (DeWitte, 2018) ve eski yazıtlar, nüfus sayımları, kilise kayıtları ve literatür kaynaklarından yararlanan bir çalışma alanıdır (Hoppa, 2002).

Anadolu'da yapılan kazılar ve çalışmalar sonucu, Neolitik dönemden Bizans'a kadar farklı dönemleri kapsayan geniş birinsan iskelet serileri ortaya çıkarılmıştır. Bu serilerin antropolojik analizi ile sadece yaşam biçimi, beslenme, sağlık durumları değil aynı zamanda yaş ve cinsiyet hakkında da önemli bilgilere ulaşılmaktadır. $\mathrm{Bu}$ çalışmanın amacı, bir zamanlar Anadolu'da yaşamını sürdürmüş olan Kayalıpınar insanlarının iskelet materyallerine dayanarak paleodemografik yapısını belirlemek, aynı dönemle ilisskili eski Anadolu toplulukları ile olan benzerlik ve/veya farklılıklarını ortaya koymaktır.

\section{Gereç ve Yöntem}

Çalışma örneklemini, Sivas İli Yıldızeli İlçesi'nde yer alan Kayalıpınar arkeolojik kazilarından elde edilen insan iskelet topluluğu oluşturmaktadır (Resim 1) (Müller-Karpe ve Müller-Karpe, 2012). Yerleşim birimindeki kazı çalışmaları ilk kez 2005 yılında başlamıştır (Müller-Karpe ve Müller-Karpe, 2006, 2012) ve o zamandan beri Vuslat Müller-Karpe yönetiminde devam etmektedir. Arkeolojik kazılarda Kayalıpınar'da 6 farklı yapı tabakası izi belirlenmiştir. Açığa çıkarılan iskelet kalıntıları, yerlessimin "Tabaka 1" adı verilen en üstteki yapı katından (Müller-Karpe ve Müller-Karpe, 2012) ve lahit, taş, çömlek ve basit toprak olmak üzere farklı mezarlardan elde edilmiştir (Müller-Karpe, 2006; Müller-Karpe ve Müller-Karpe, 2009).

Kayalıpınar yerleşim alanının güneydoğu tepesi 1 . Tabaka'da Hellenistik'ten Erken Bizans'a kadar mezarlık olarak işlev görmüştür. Erken döneme ait gömüler kazı alanının güneyinde; sırtüstü, başlar doğuda ve ayaklar batı yönde uzanır. Bu gömülerde mezar eşyası az ve birçoğu takılardan oluşur. Geç döneme ait gömüler kazı alanının geneline yayılmış olup çok kez kuzeyde yer alır. Baş batıda ve doğu yönüne bakmaktadır. Bu gömülerde mezar eşyası minimum sayıdadır. Geç döneme ait mezarların gömü özelliklerine dayanılarak Hırıstiyan bir halkın burada olduğu üzerinde durulmuş, Geç RomaErken Bizans olarak tarihlendirilmiştir (Müller-Karpe ve Müller-Karpe, 2012). İskeletlerin korunma durumu erozyon ve tarım kaynaklı dış etkenlere bağlı olarak değişkenlik göstermektedir (Müller-Karpe ve MüllerKarpe, 2006).

Çalışma malzemesini oluşturan iskelet kalıntıları Cumhuriyet Üniversitesi Antropoloji Bölümü

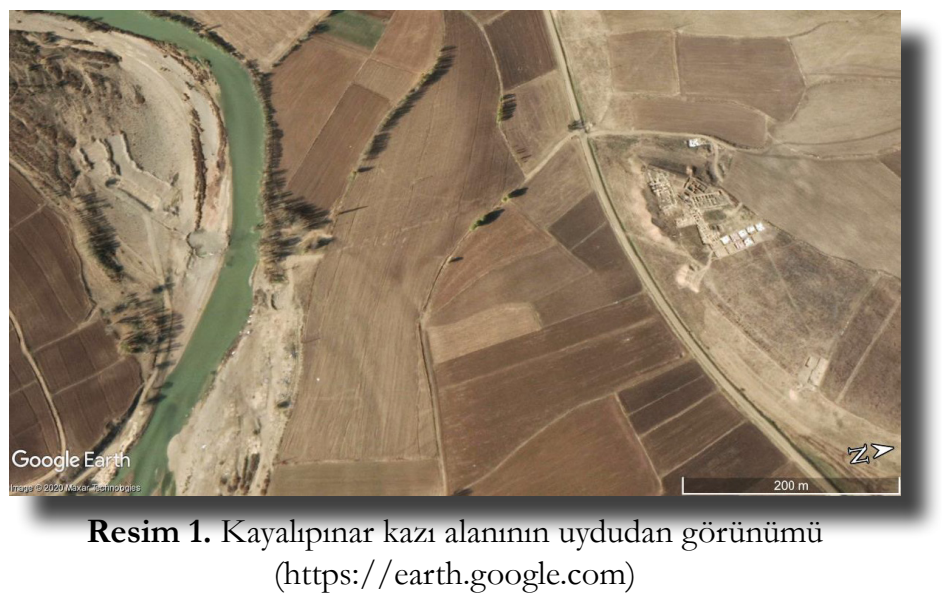

Laboratuvarında muhafaza edilmektedir. Temizlik ve onarım işlemlerinin ardından iskeletler üzerinde antropolojik analizler yapılabilmiştir. Bireylerin yaşları belirlenmiş ve cinsiyetleri tayin edilmiştir. Toplum $0-2,5$ yaş bebek, 2,5-18 yaş çocuk, 18-30 yaş genç erişkin, 3045 yaş orta erişkin, 45 yaş ve üzeri ise ileri erişkin olacak şekilde yaş gruplarına bölünmüştür.

Cinsiyet tayin edilirken kafatas1 ve leğen kemiğindeki (pelvis) temel belirleyici karakterler göz önünde bulundurulmuş (WEA, 1980), her ikisinin olmadığ1 durumlarda ise mevcut kemiklerde morfolojik özelliklere bakılmıs, diskriminant analizi metodundan yararlanılmıştır (Özer ve Sağır, 2003). Yaş belirlenirken, bebek ve çocuklarda dişlerin kalsifikasyon süreci (Ubelaker, 1989; Sağır, 2013), genç erişkinlerde epifizlerin kaynaşma yaşları (WEA, 1980; Brothwell, 1981), erişkinlerde ise süngerimsi doku yoğunluğu (Szilvàssy ve Kritscher, 1990), clavicula kortikal kesiti (Kaur ve Jit, 1990), sutural yaşlandırma (Olivier, 1969), facies auricularis (Lovejoy vd., 1985) ve symphysis pubis'in (Buikstra ve Ubelaker, 1994) yaş artışına bağlı olarak farklılaşan morfolojilerinden yararlanılmıştır. Son olarak Kayalıpınar insanları ile ilgili yaşam tablosu düzenlenirken Ubelaker (1989) formülü kullanılmıştır.

\section{Bulgular}

Antropolojik inceleme sonucunda Kayalipinar topluluğundaki birey sayıs1 211 olarak belirlenmiştir (Tablo 1). Erişkinler \%81,52 ile topluluğun büyük bölümünü oluşturur (Grafik 1). Bebek ve çocuk ölümlülüğü birçok eski Anadolu toplumuna göre oldukça düşüktür ve toplumun sadece $\%$ 18,48’ini bu yaş grubu oluşturur. Toplulukta fetal dönemde ya da doğum sirasinda ölen bebeklere ilişkin herhangi bir kanıt yoktur. Kadınlar çok az bir farkla erkeklerden fazladır. Paleodemografik bir çalışmada topluluktaki kadın/erkek oranının 1:1 olması beklenmektedir ve elde ettiğimiz 1,15 sonucu da bahsi geçen orana bir hayli yakın çıkmıştır. Bu durum, Kayalıpınar toplumunda her bir kadına karşı bir erkek bireyin karşılık geldiği şeklinde 
Tablo 1. Kayalıpınar topluluğunun demografik özellikleri

\begin{tabular}{ccc}
\hline Demografik Dağıım & Birey Sayısı & $\%$ \\
\hline Bebek (0-2,5 yaş) & 10 & 4,74 \\
Çocuk (2,5-18 yaş) & 29 & 13,74 \\
Kadın (18+ yaş) & 90 & 42,65 \\
Erkek (18+ yaş) & 78 & 36,97 \\
Erişkin Belirsiz (18+ yaş) & 4 & 1,90 \\
TOPLAM & 211 & 100 \\
\hline
\end{tabular}

yorumlanabilir.

Kayalıpınar toplumunda 18 yaş ve üzerindeki bireyler erişkin olarak tanımlanmıştır. Erişkinler kendi içerisinde analiz edildiğinde Tablo 2'deki sonuçlara ulaşılmıştır. Orta erişkin yaş grubundaki bireyler erişkinler arasında sayısal olarak fazladır. Yaşlı olarak tanımlanan bireyler erişkinler içerisinde \%10,47’lik (18 birey) bir bölüme denk gelir. Cinsiyetler arasındaki duruma bakıldığında, kadın ve erkeklerin orta erişkin yaş grubunda daha çok toplandığı görülür. Kadınlarda genç erişkin, erkeklerde ise yaşlı (ileri erişkin) bireylerin sayısal üstünlüğü göze çarpmaktadır. Erişkin olmakla birlikte yaşları belirlenemeyen (erişkin belirsiz) birey sayıs1 14'tür.

Toplulukların demografik özellikleri ile ilgili ayrıntılı veriler en iyi şekilde yaşam tablosundan elde edilir. Bir yaşam tablosuna bakılarak doğum, ölüm, sağlık, yaşam beklentisi ve nüfusun genel durumu hakkında çarpıc1 bilgilere ulaşılabilir. Yaşam tabloları birerli ve beşerli yaş aralıklarına göre iki farklı şekilde düzenlenir. Burada bebek ve çocuklarda yaşın kesin olarak belirlenebilmesi, erişkinlerde ise yaş belirlenirken hata payının görece daha yüksek olması etkilidir.

Tablo 3 incelendiğinde, bebek ve çocuklarda ölümler sırasıyla 4-5, 2-3 ve $0-1$ yaş grubunda yüksektir. 39 bebek ve çocuğun \%46,15’i (18 birey) ilk beş yılda yaşamını yitirmiştir. İlk bir yil içerisinde sadece 4 birey olup, ikisi yeni doğan (doğum \pm 2 ay ve 40 hafta), diğer ikisi de 9 aylık bebeklerdir. 0-1 yaş arasında yaşam beklentisi 7 yıl

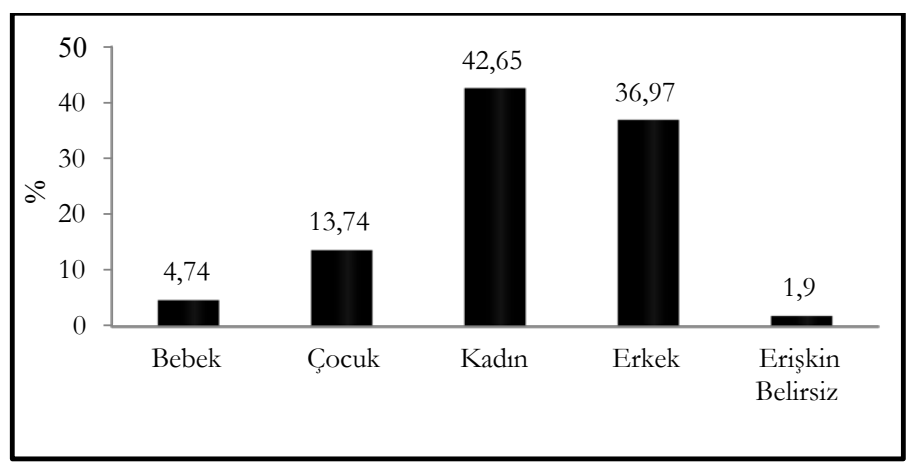

Grafik 1. Kayalıpınar insanlarının demografik dağılımı (\%: Oransal değer)

civarındadır. 5-6, 8-9 ve 13-14 yaş aralıklarındaki yaşam beklentisinde bir öncekine göre küçük artışlar gözlenmiştir. Bununla birlikte hayatta kalma şansı beş yaşından başlamak üzere hızlı bir düşüş sergilemektedir (Tablo 3 ve Grafik 2).

Kayalıpınar kadın ve erkeklerine ait yaşam tablosu bulguları Tablo 4 ve 5'te yer almaktadır. Ölümler erkeklerde 35-40, kadınlarda ise 20-25 yaş grubunda yüksektir. Kadınlarda doğurganlığın bu yaş aralıklarında yüksek olması ve/veya beklenmesi ölüm oranını açıklayıcı bir durum olarak düşünülebilir. 18-20 yaş grubundaki genç erişkin bir erkek için yaşam beklentisi 19,97 yıl, genç erişkin bir kadın için ise 17,62 yıldır ve aralarındaki fark erkekler lehine 2,35 yıl daha fazladır. Erkekler de yaşam beklentisi 40-45 yaş aralığına kadar azalmakta, bu yaş grubunda hafif bir artma eğiliminde olmakta ve sonrasinda ise tekrar düşüş göstermektedir. Kadınlar da ise yaş arttıkça yaşam beklentisinde sürekli bir azalış göze çarpmaktadır (Tablo 4, 5 ve Grafik 3, 4).

Kayalıpınar topluluğunda yaşı belirlenebilen 197 birey için düzenlenen yaşam tablosuna göre, ölüm sıklığı $35-40(\% 23,35)$ ve $20-25(\% 17,26)$ yaş grubunda en yüksek, $10-15(\% 2,54)$ ve $15-20(\% 2,54)$ yaş grubunda ise en düşüktür. Toplulukta ilk beş y1l içerisindeki ölüm oranı sadece $\% 9,14$ 'tür. 25 ve 35 yaşla beraber hayatta kalma şansında belirgin bir çöküş tespit edilmiştir. 0-5 yaş grubundaki yaşam beklentisi 28,24 yıldır. Yaş arttıkça yaşam beklentisi de azalır ve 30 yaşla birlikte tek haneli rakama iner. Yaşam beklentisi 15 yaşına kadar 20 yıl

Tablo 2. Erişkinlerin cinsiyete göre sınıflandırılması

\begin{tabular}{ccccccccc}
\hline \multirow{2}{*}{$\begin{array}{c}\text { E r iş k i n } \\
\text { Bireyler }\end{array}$} & \multicolumn{2}{c}{ Kadın } & \multicolumn{2}{c}{ Erkek } & Belirsiz Erişkin & \multicolumn{2}{c}{ TOPLAM } \\
\cline { 2 - 8 } & $\mathrm{N}$ & $\%$ & $\mathrm{~N}$ & $\%$ & $\mathrm{~N}$ & $\%$ & $\mathrm{~N}$ & $\%$ \\
\hline Genç E. & 32 & 35,56 & 18 & 23,08 & 2 & 50 & 52 & 30,23 \\
Orta E. & 44 & 48,89 & 44 & 56,41 & - & - & 88 & 51,16 \\
Ileri E. & 7 & 7,78 & 11 & 14,10 & - & - & 18 & 10,47 \\
Belirsiz E. & 7 & 7,78 & 5 & 6,41 & 2 & 50 & 14 & 8,14 \\
TOPLAM & 90 & 100 & 78 & 100 & 4 & 100 & 172 & 100 \\
\hline
\end{tabular}




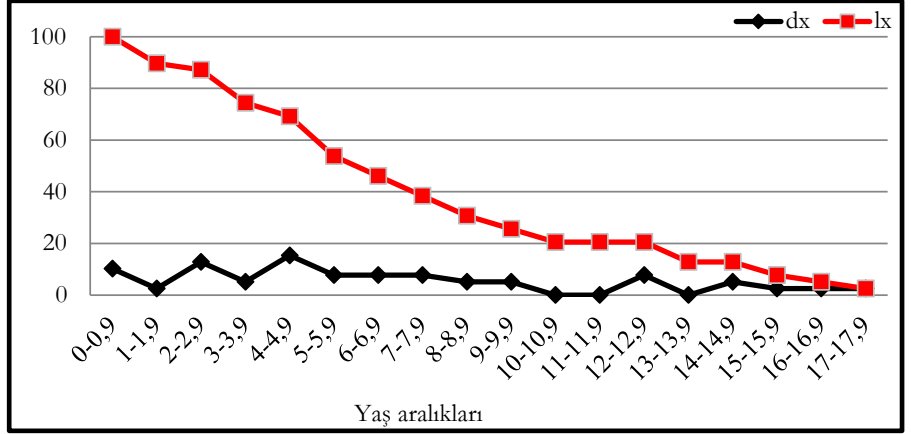

Grafik 2. Bebek ve çocuklarda ölüm oranı ve hayatta kalma şansı (dx: Yaş aralığındaki ölenlerin yüzdesi, lx: Yaş aralığındaki hayatta kalanların sayıs1)

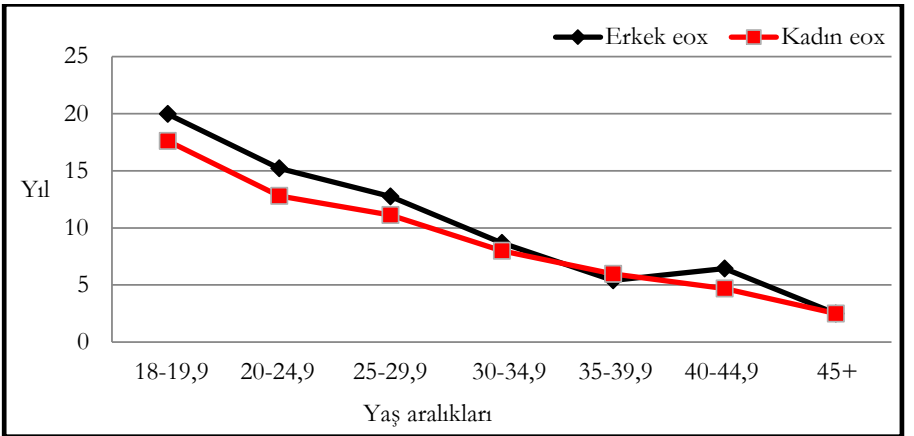

Grafik 4. Kadın ve erkeklerde yaşam beklentisi (Ex: Yaşam beklentisi)

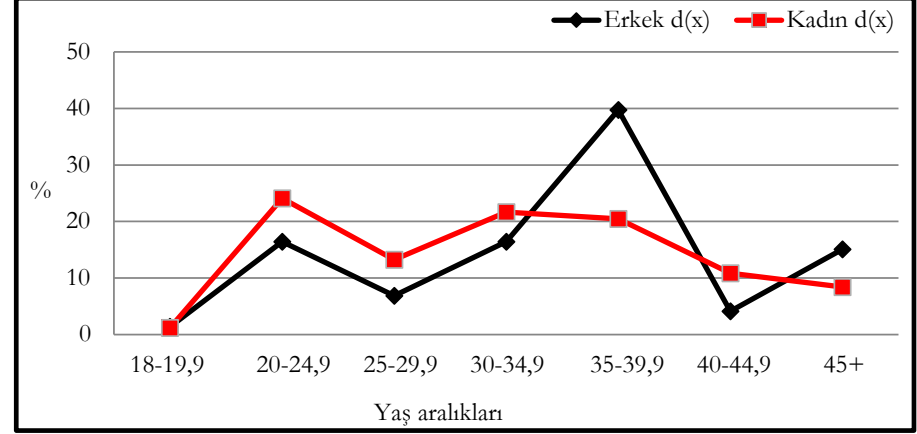

Grafik 3. Kadın ve erkeklerdë ölüm oranları (dx: Yaş aralığındaki ölenlerin yüzdesi, \%: Ölüm oranı ekseni)

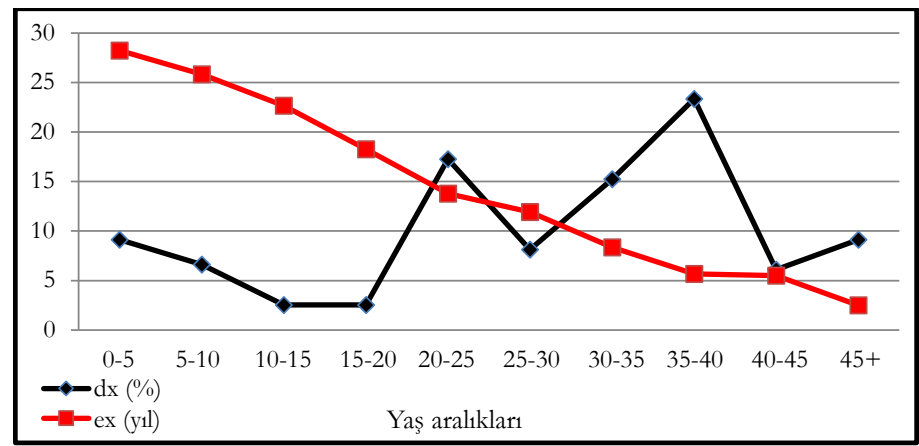

Grafik 5. Kayalıpınar insanlarındä ölüm oranları ve yaşam beklentisi (dx: Yaş aralığındaki ölenlerin yüzdesi, ex: Yaşam beklentisi)

Tablo 3. Bebek ve çocukların yaşam tablosu

\begin{tabular}{cccccccc}
\hline $\mathbf{X}$ & $\mathbf{D}(\mathbf{x})$ & $\mathbf{d}(\mathbf{x})$ & $\mathbf{1}(\mathbf{x})$ & $\mathbf{q}(\mathbf{x})$ & $\mathbf{L}(\mathbf{x})$ & $\mathbf{T}(\mathbf{x})$ & $\mathbf{e}^{\mathbf{0}} \mathbf{x}$ \\
\hline $0-0,9$ & 4 & 10,26 & 100 & 0,10 & 94,87 & 667,95 & 6,68 \\
$1-1,9$ & 1 & 2,56 & 89,74 & 0,03 & 88,46 & 573,08 & 6,39 \\
$2-2,9$ & 5 & 12,82 & 87,18 & 0,15 & 80,77 & 484,62 & 5,56 \\
$3-3,9$ & 2 & 5,13 & 74,36 & 0,07 & 71,79 & 403,85 & 5,43 \\
$4-4,9$ & 6 & 15,38 & 69,23 & 0,22 & 61,54 & 332,05 & 4,80 \\
$5-5,9$ & 3 & 7,69 & 53,85 & 0,14 & 50,00 & 270,51 & 5,02 \\
$6-6,9$ & 3 & 7,69 & 46,15 & 0,17 & 42,31 & 220,51 & 4,78 \\
$7-7,9$ & 3 & 7,69 & 38,46 & 0,20 & 34,62 & 178,21 & 4,63 \\
$8-8,9$ & 2 & 5,13 & 30,77 & 0,17 & 28,21 & 143,59 & 4,67 \\
$9-9,9$ & 2 & 5,13 & 25,64 & 0,20 & 23,08 & 115,39 & 4,50 \\
$10-10,9$ & 0 & 0 & 20,51 & 0 & 20,51 & 92,31 & 4,50 \\
$11-11,9$ & 0 & 0 & 20,51 & 0 & 20,51 & 71,80 & 3,50 \\
$12-12,9$ & 3 & 7,69 & 20,51 & 0,38 & 16,67 & 51,28 & 2,50 \\
$13-13,9$ & 0 & 0 & 12,82 & 0 & 12,82 & 34,62 & 2,70 \\
$14-14,9$ & 2 & 5,13 & 12,82 & 0,40 & 10,26 & 21,80 & 1,70 \\
$15-15,9$ & 1 & 2,56 & 7,69 & 0,33 & 6,41 & 11,54 & 1,50 \\
$16-16,9$ & 1 & 2,56 & 5,13 & 0,50 & 3,85 & 5,13 & 1,00 \\
$17-17,9$ & 1 & 2,56 & 2,57 & 1 & 1,29 & 1,28 & 0,50 \\
\hline & & & & & & \\
\hline
\end{tabular}


Sar1 ve Sağır| Antropoloji (39) (2020)

Tablo 4. Erkeklerde yaşam tablosu bulguları

\begin{tabular}{|c|c|c|c|c|c|c|c|}
\hline $\mathbf{X}$ & $\mathrm{D}(\mathrm{x})$ & $d(x)$ & $1(x)$ & $q(x)$ & $\mathrm{L}(\mathrm{x})$ & $T(x)$ & $e^{0} x$ \\
\hline 18-19,9 & 1 & 1,37 & 100 & 0,01 & 496,58 & 1996,58 & 19,97 \\
\hline $20-24,9$ & 12 & 16,44 & 98,63 & 0,17 & 452,05 & 1500,00 & 15,21 \\
\hline $25-29,9$ & 5 & 6,85 & 82,19 & 0,08 & 393,84 & 1047,95 & 12,75 \\
\hline $30-34,9$ & 12 & 16,44 & 75,34 & 0,22 & 335,62 & 654,11 & 8,68 \\
\hline $35-39,9$ & 29 & 39,73 & 58,90 & 0,67 & 195,21 & 318,50 & 5,41 \\
\hline $40-44,9$ & 3 & 4,11 & 19,18 & 0,21 & 85,62 & 123,29 & 6,43 \\
\hline $45+$ & 11 & 15,07 & 15,07 & 1 & 37,67 & 37,68 & 2,50 \\
\hline
\end{tabular}

X: Yaş aralığı. D(x): Yaş aralı̆̆ındaki ölenlerin sayısı. d(x): Yaş aralığındaki ölenlerin yüzdesi. 1(x): Yaş aralığındaki hayatta kalanların sayısı. $\mathbf{q ( x ) : ~ Y a s ̧ ~ a r a l ı g ̆ ı n d a k i ~ o ̈ l u ̈ m ~ o l a s ı l ı g ̆ ı . ~} \mathbf{L}(\mathbf{x})$ : Yaş arağındaki bireyler tarafindan yaşanılan toplam yıl sayısı. T(x): Yaş aralığındaki bireylerin yaşam sürelerinde kalan toplam yıl sayısı, $\mathbf{e}^{\mathbf{0}} \mathbf{x}$ : Yaşam beklentisi.

Tablo 5. Kadınlarda yaşam tablosu bulguları

\begin{tabular}{|c|c|c|c|c|c|c|c|}
\hline $\mathbf{X}$ & $\mathrm{D}(\mathrm{x})$ & $d(x)$ & $1(x)$ & $q(x)$ & $\mathbf{L}(\mathbf{x})$ & $T(x)$ & $e^{0} x$ \\
\hline $18-19,9$ & 1 & 1,20 & 100 & 0,01 & 496,99 & 1762,05 & 17,62 \\
\hline $20-24,9$ & 20 & 24,10 & 98,80 & 0,24 & 433,73 & 1265,06 & 12,80 \\
\hline $25-29,9$ & 11 & 13,25 & 74,70 & 0,18 & 340,36 & 831,33 & 11,13 \\
\hline $30-34,9$ & 18 & 21,69 & 61,45 & 0,35 & 253,01 & 490,97 & 7,99 \\
\hline $35-39,9$ & 17 & 20,48 & 39,76 & 0,52 & 147,59 & 237,95 & 5,98 \\
\hline $40-44,9$ & 9 & 10,84 & 19,28 & 0,56 & 69,28 & 90,36 & 4,69 \\
\hline $45+$ & 7 & 8,43 & 8,43 & 1 & 21,08 & 21,09 & 2,50 \\
\hline
\end{tabular}

X: Yaş aralığı. $\mathbf{D}(\mathbf{x})$ : Yaş aralığındaki ölenlerin sayısı. $\mathbf{d}(\mathbf{x})$ : Yaş aralığındaki ölenlerin yüzdesi. 1(x): Yaş aralığındaki hayatta kalanların sayısı. q(x): Yaş aralığındaki ölüm olasılığı. L(x): Yaş arağındaki bireyler tarafindan yaşanılan toplam yıl sayısı. T(x): Yaş aralığındaki bireylerin yaşam sürelerinde kalan toplam yıl sayısı, $\mathbf{e}^{\mathbf{0}} \mathbf{x}$ : Yaşam beklentisi.

Tablo 6. Kayalıpınar toplumunun genel yașam tablosu

\begin{tabular}{|c|c|c|c|c|c|c|c|}
\hline $\mathbf{X}$ & $\mathrm{D}(\mathrm{x})$ & $d(x)$ & $1(x)$ & $q(x)$ & $\mathrm{L}(\mathrm{x})$ & $T(x)$ & $e^{o} x$ \\
\hline $0-5$ & 18 & 9,14 & 100 & 0,09 & 477,16 & 2823,6 & 28,24 \\
\hline $5-10$ & 13 & 6,60 & 90,86 & 0,07 & 437,82 & 2346,44 & 25,82 \\
\hline $10-15$ & 5 & 2,54 & 84,26 & 0,03 & 414,97 & 1908,63 & 22,65 \\
\hline $15-20$ & 5 & 2,54 & 81,73 & 0,03 & 402,28 & 1493,65 & 18,28 \\
\hline $20-25$ & 34 & 17,26 & 79,19 & 0,22 & 352,79 & 1091,37 & 13,78 \\
\hline $25-30$ & 16 & 8,12 & 61,93 & 0,13 & 289,34 & 738,57 & 11,93 \\
\hline $30-35$ & 30 & 15,23 & 53,81 & 0,28 & 230,96 & 449,23 & 8,35 \\
\hline $35-40$ & 46 & 23,35 & 38,58 & 0,61 & 134,52 & 218,27 & 5,66 \\
\hline $40-45$ & 12 & 6,09 & 15,23 & 0,40 & 60,91 & 83,75 & 5,50 \\
\hline $45+$ & 18 & 9,14 & 9,14 & 1 & 22,84 & 22,84 & 2,50 \\
\hline
\end{tabular}

X: Yaş aralığı. D(x): Yaş aralığındaki ölenlerin sayısı. d(x): Yaş aralığındaki ölenlerin yüzdesi. 1(x): Yaş aralığındaki hayatta kalanların sayısı. $\mathbf{q}(\mathbf{x})$ : Yaş aralığındaki ölüm olasılığı. $\mathbf{L}(\mathbf{x})$ : Yaş arağındaki bireyler tarafindan yaşanılan toplam yıl sayısı. T(x): Yaş aralı̆̆ındaki bireylerin yaşam sürelerinde kalan toplam yıl sayısı, $\mathbf{e}^{\mathbf{0}} \mathbf{x}$ : Yaşam beklentisi. 
Sar1 ve Sağır $\mid$ Antropoloji (39) (2020)

Tablo 7. Bazı Eski Anadolu topluluklarında bebek ve çocuk ölüm oranları

\begin{tabular}{|c|c|c|c|}
\hline Araştırmacı & Dönem & Toplum & $\%$ \\
\hline Atamtürk ve Duyar, 2008 & M.S. 5-6. yy & Adramytteion (Örentepe) & 21,43 \\
\hline Karaöz Arrhan ve Acar, 2015 & M.S. 9-12.yy & Giresun Adas1 & 14,53 \\
\hline Erdal, 2010 & M.S.1020-1077 $\pm 20^{*}$ & Oluz & 65,6 \\
\hline Erdal, 1999 & Hellenistik-Roma & Cevizcioğlu Çiftliği & 20,7 \\
\hline Erdal vd., 2003 & Hellenistik-Erken Roma & İzmir/Şaşal & 21,37 \\
\hline Bu Çalışma & Hellenistik-Erken Bizans & Kayalıpinar & 18,48 \\
\hline Sağır vd., 2004 & Geç Geometrik-Roma & Börükçü & 16,67 \\
\hline Çırak vd., 2019 & Roma & Parion & 21,2 \\
\hline Gözlük Kırmızıoğlu ve Sevim Erol, 2017 & Roma & Aziz Mercurius & 70,37 \\
\hline Şahin vd., 2015 & Roma & Pinarkent & 15,38 \\
\hline Alpagut ve Erdoğan, 2016 & Geç Roma & Dara & 17,59 \\
\hline Çırak, 2017 & Geç Roma-Bizans & Akgüney & 20 \\
\hline Üstündağ ve Demirel, 2009 & Bizans & Alanya Kalesi & 22,2 \\
\hline Erdal, 1996 & Geç Bizans & İznik & 16,67 \\
\hline Üstündağ, 2009 & Geç Bizans & Kadikalesi & 50 \\
\hline Yaşar, 2007 & Ortaçă̆ & Minnetpinar1 & 17,44 \\
\hline Erkman, 2008 & Ortaçă̆ & Van Dilkaya & 51,10 \\
\hline Gözlük, 2004 & Ortaçă̆ & Van Karagündüz & 58,20 \\
\hline Koruyucu, 2012 & Ortaçă̆ & Köşk Höyük & 52,4 \\
\hline
\end{tabular}

* Erdal vd., 2015 çalışmasında iki bireyden elde edilen ve kalibre edilmiş C14 tarihlendirme sonucudur.

üzerindeyken, 15 yaşla birlikte 20 y1lın altına düşmekte ve kademeli olarak azalmaktadır (Tablo 6 ve Grafik 5).

\section{Tartışma}

Orta Anadolu'nun doğusunda bulunan ve tarihi Hellenistik-Erken Bizans'a uzanan Kayalipınar sakinleri hakkında yukarıda anlatılanlar, topluluk paleodemografisinin iç dinamiklerine 1 şı tutması açısından önemli bilgiler kazandırmışır. Kayalıpınar arkeolojik kazılarının devam etmesi ve mezarlık alanındaki çalışmalara ara verilmiş olmasına karşın, mevcut iskeletler üzerindeki demografi ile ilişkili antropolojik analizlerin anlamlı sonuçlar verdiği düşünülmektedir.

Bir toplumdaki yaş-cinsiyet durumu topluluktaki tüketicilerin üreticilere oranını ve kadın-erkek (evlilik) ilişkilerini etkiler ve böylece geçim stratejileri ve hane halk1 yap1s1 gibi birtakım olaylar üzerinde sinırlamalar oluşturur. Benzer şekilde aileler ve topluluklar arasındaki ekonomik ilişkilere de etki eder. Çünkü kültürler bireylerin cinsiyetine ve kimi zamanda yaşlarına bağlı olan, dolayısıyla demografik yapıdan önemli ölçüde etkilenen bazı kuralları içerir (DeWitte, 2018). Kayalıpınar topluluğu 90 kadın, 78 erkek, 10 bebek, 29 çocuk ve 4 cinsiyeti belirsiz erişkin olmak üzere toplam 211 bireyle temsil edilir. 18 yaş ve üzeri erişkin birey sayıs 172'dir. Bebek ve çocuklara ait iskelet materyalleri erişkinlere göre daha azdır. Normal bir toplulukta olması beklenen kadın, erkek, bebek ve çocuklar çalışma serimizde de temsil edilir. Ayrıca yaş dağılımı açısından bakıldığında, fetüs hariç her yaştan bireyin olduğu da görülebilir. Bu anlamda eldeki bulgular Kayalıpınar insanlarının demografik zenginliğini bizlere yansıtır.

Yaşam biçimi her bir toplumda değişmekte, toplum içerisinde meydana gelen en küçük bir değişikliğin etkisi de en fazla bebek ve çocuklarda hissedilmektedir (Özbek ve Erdal, 2006). Eski Anadolu topluluklarında nüfusun büyük bir bölümünü bebek ve çocukların oluşturduğu varsayllır (Büyükkarakaya vd., 2018) ve oransal olarak farklılık göstermekle birlikte literatür çalışmalarında yüksek sıklığ1 üzerinde durulur (Erdal, 2000, 2013; Demirel, 2017). Oransal dağılım dönemsel olarak da 
farklılaşır. Neolitik'te \% 31,22, Kalkolitik'te \%29, Tunç Çağı'nda \%44,08, Demir Çağı'nda \%29,11, HellenistikRoma'da \%25,75 ve Anadolu Ortaçağı'nda \%38,13 olarak hesaplanmıştır (Koca Özer vd., 2008, 2014).

Bebek ve çocuk ölümlüğü eski Anadolu topluluklarının yaşadığı çevre, sosyo-ekonomik gelişmişlik düzeyi, sağlık durumu ve beslenme yapısı hakkında ipuçları vermeleri nedeniyle önem arz etmektedir (Başoğlu ve Şener, 2015). HellenistikErken Bizans dönemine ait çalışma materyalimizdeki bebek ve çocuk ölüm oranı $\% 18,48$ 'tir ve yukarıda değinilen Hellenistik-Roma ve Anadolu Ortaçağı'na ait oranların altında kalmaktadır. Kayalıpınar özelinde bakılacak olursa, yerleşim alanının uzunca bir süre tarım alanı olarak kullanılması ve her yıl belirli dönemlerde tarım makineleri aracılığıyla ekim yapilabilecek duruma getirilmesi mezarlik alanda bir tahribat yaratmış olmalıdır. Şöyle ki toplum sakinlerine ait iskelet bütünlüğü bireyden bireye değişmekte, ele geçen materyal sayısı bazı bireylerde görece sinırlı sayıda bulunmaktadır. Ayrıca mezarlık alanındaki çalışmaların tamamlanmasındaki eksiklik bebek ve çocukları erişkinlere göre daha fazla etkilemiş olabilir. Tüm bu etkenler Kayalıpınar bebek ve çocuk ölümleri hakkında değerlendirme yapmamızı güçleştirmektedir.

Mevcut değerimiz $(\% 18,48)$, eski Anadolu topluklarından Örentepe \%21,43 (M.S. 5-6. yy), Giresun Adası \%14,53 (M.S. 9-12. yy), Cevizcioğlu Çiftliği \%20,7 (Hellenistik-Roma), İzmir / Şaşal \%21,37 (HellenistikErken Roma), Börükçü \% 16,67 (Geç GeometrikRoma), Dara \%17,59 (Geç Roma), Pinarkent \%15,38 (Roma), Parion \%21,2 (Roma), Akgüney \%20 (Geç Roma-Bizans), İznik \%16,67 (Geç Bizans), Alanya Kalesi \%22,2 (Bizans) ve Minnetpınarı \%17,44 (Ortaçă̆) toplumlarına oldukça yakındır (Tablo 7). Benzer şekilde Aziz Mercurius \%70,37 (Roma), Kadikalesi \%50 (Geç Bizans), Oluz \%65,6 (M.S. 1020-1077 \pm 20$)$, Van Dilkaya $\% 51,10$ (Ortaçağ), Van Karagündüz \%58,20 (Ortaçağ) ve Köşk Höyük \%52,4 (Ortaçağ) topluluklarına ise bir o kadar uzaktır (Tablo 7). Demirel (2017), Erken Bizans'ta yüksek olan bebek ve çocuk ölümlerinin Orta Bizans'ta gerilediğini ifade eder. Tritsaroli ve Karadima (2017), Maroneia/Yunanistan (Erken Bizans) insanlarındaki bebek ve çocuk ölüm oranını \%12,82 olarak belirtmiştir. $\mathrm{Bu}$ değer ise Kayalıpınar'daki orandan düşüktür.

Bebek ve çocuk ölüm oranındaki çeşitliliğe birtakım sebepler yol açabilir. Mezarlıktaki kazı çalışmalarının tamamlanmaması, iskelet kalıntılarının kolaylıkla zarar görmesi ve gözden kaçması, kültürel uygulamalar, mezar derinliğinin az olması ve çürüme evresinin erişkinlere kıyasla daha az zaman alması gibi nedenler siralanabilir (Özbek ve Erdal, 2006). Bununla beraber yaşam kalitesinin iyi ve sosyo-ekonomik koşulların elverişli olduğu topluluklarda ölümlülüğün düşük oranlarda seyrettiği belirtilir (Demirel, 2017). Yerleşik yaşam neticesinde artan nüfus, göç, ticaret, hayvanlarla olan yakın temas ve besinlerdeki bozulma ölümleri tetiklemiştir. Enfeksiyonlar ve metabolik hastalıklar ise en önemli sorunlardır (Erdal, 2000). Yaşamın ilk birkaç yılında gözlenen ölümlerde beslenme, doğum travmas1, enfeksiyon, salgınlar, çevresel stres, bulaşıcı ve solunum sistemi hastalıkları, anemi, hijyen, doğum sıklığı, annenin bebek bakımındaki eksiklikleri ve sosyoekonomik yap1 sorumlu tutulabilir (Güleç, 1988; Özbek ve Erdal, 2006; Demirel, 2013; Büyükkarakaya, 2017).

Eski Anadolu topluluklarında yaşamın ilk beş yılı içerisinde ve çoğunlukla bir yaş altında gözlenen ölüm oranındaki artış birçok çalışma tarafından doğrulanmıştır (Güleç, 1988; Erdal, 2000; Nalbantoğlu vd., 2000). Parion Roma'da ilk beş y1l içerisindeki ölümler yaşı belirlenen bireylerin (26 birey) \%11,53'ünü, 15 yaş altındaki ölümler ise \%26,92'sini temsil eder (Çırak vd., 2019). Spradon Geç Roma-Erken Bizans'ta 0-5 yaş aralığındaki ölümler toplumun (79 birey) \%12,66'sın1, 15 yaş altı ölümler ise \% 19'unu oluşturur (Çırak vd., 2018). Topaklı Erken Bizans'ta 0-5 yaş arasindaki ölümler nüfusun (187 birey) \%20,3’ünü, 15 yaş altı ölümler ise nüfusun \%47'sini kapsar (Güleç, 1988). Yortanlı Geç Bizans'ta ilk beş yaştaki ölümler topluluğun (107 birey) yaklaşık \%15'ini oluşturur (Nalbantoğlu vd., 2000). Kelenderis 19. ve Aziz Nikolaos 20. yüzyıl topluluklarında beş yaş altındaki ölümler sırasıyla \%28,18 ve \%22,22 iken, 15 yaş altındaki ölümlerin oranı da sırasıyla $\% 35,45$ ve \%29,62'dir (Erdal, 1997; Çırak, 2009). Demirel (2013), Orta Bizans'a tarihlendirilen Amorium kentinde sadece bebek ve çocuklardan oluşan 128 bireyi incelemiştir. Yazar bireylerin \%49,2'sinin doğum öncesi veya doğum sırasında, \%39,06'sının 0-3 yaş ve \%4,7'sinin 3-10 yaş aralığında öldüklerine değinmiştir.

TUIK verileri, Türkiye'de 2009'dan 2016 y1lına kadar olan sürede 15 yaş altındaki ölümlerin \%33,7 oranında azaldığını, 5 yaş altındaki ölümlerde ise ciddi düşüşlerin olduğuna işaret eder. Fakat 15 yaş altındaki ölümlerden bir yaşına kadar olanlar \%65'in üstündedir ve ölümler çok kez ilk bir ayda yaşanmaktadır (Gümüş vd., 2018). Bu sonuçlar geçmişte olduğu gibi günümüzde de $0-5$ ve $0-1$ yaş arasındaki ölümlerin üzerinde durulması gerektiğini açılar. Kayalıpınar sakinlerinde yaşı belirlenen nüfusun (197 birey) 0-5 yaş aralı̆̆ındaki ölüm oranı \%9,14 iken 15 yaş altı ölüm oranı ise \%18,28'tir. Beş yaş altı ölüm oranı $(\% 9,14)$ Parion, Spradon ve Yortanlı topluluklarına yakınlık gösterir. Sadece bebek ve çocuklar göz önüne alındığında ise, beş yaş altında yaşamını yitirenlerin oranı $\% 46,15$ 'e çıkmaktadır ve ölümler $0-5$ yaş grubunda $4-5$, $2-3$ ve $0-1$ yaş arasında artış göstermiştir. Toplulukta ilk beş yaş içerisinde 18, ilk bir yaş içerisinde ise sadece 4 birey bulunmaktadır. 0-1 yaş arasındaki birey sayısının bu kadar az olması beklenilen bir durum değildir ve 
araștırılması gereken bir konudur.

Kayalıpınar toplumunda daimi dişlerde gözlenen mine hipoplazilerinin (lineer) ortaya çıkış yaşı ile ilgili yapılan bir çalışma (yayına hazırlanıyor), erken yaşlarda gözlenen ölümleri açıklayabilir. Hipoplaziler 1-2 yaş arasında en düşük, 4-5 yaş arasında ise en yüksek orana sahiptir. 5 yașina kadar kademeli olarak artan kusur oranı sonrasında ani bir azalma eğilimindedir. Ortalama olarak 1,5 yaşın biraz üzerinde dişlerde görülmeye başlayan kusur, 6 yaşına kadar dişleri etkilemiştir. Yapılan çalışmalarda mine kusuruna yol açan birçok faktörün olduğu stralanmakta, sistemik fizyolojik streslerin ise en çok kabul gören etken olduğu belirtilmektedir (Goodman ve Rose, 1990). 2-5 yaş arasındaki ölümlerin bebeğin sütten kesilmesi ve tamamlayıc1/ek besinlerin alınmaya başlandığı dönemle paralel olduğu ifade edilir (Erdal, 2000). Üstelik bu süreçte birey çevreyi tanımakta, bağımsız olarak hareket edebilmekte ve çevre ile iç içe bulunmaktadır. Dolayısıyla patojenlere karşı savunmasız kalabilmektedir, bu ise bebek ve çocukların genel sağlık durumunu olumsuz yönde etkilemektedir.

Kayalıpınar insanları hakkında değinilmesi gereken bir diğer konu yaşam beklentisidir. Koca Özer ve ekibi (2008), yaşam beklentisinin sosyal çevre ve halk sağlığının bir belirleyicisi olduğunu; savaş, açlık, salgın ve yaygın bulaşıcı hastalıklara bağlı olarak yavaş seyreden bir artış gösterdiğini açılar. Dahası erken avc1-toplayıc1 topluluklara göre yaşam beklentisi tarım toplumlarında daha düşüktür. 0-5 yaş aralığındaki yaşam beklentisi Parion Roma için 32,69 (Çırak vd., 2019), Spradon Geç Roma-Erken Bizans için 32,68 (Çırak vd., 2018), Yortanlı Geç Bizans için 28,53 (Nalbantoğlu vd., 2000), Kelenderis 19. yüzyıl için yaklaşık 30 (Çırak, 2009) ve Aziz Nikolaos 20. yüzyıl için 30,28 (Erdal, 1997) yıldır. İznik Geç Bizans'ta cavea içi ve İznik topluluğu bütününde $0-5$ yaş grubunda sirasiyla 29,97 ve 26,13 y1l olarak yaşam beklentisi hesaplanmıştır (Erdal, 1996). Yine Elaiussa Sebaste'de (MS 6-7. yüzyıl/Bizans) yașam beklentisi yeni doğan için 24,6 yll olarak hesaplanmıştır (Paine vd., 2007). Toplumlara ilişkin sonuçlar (Parion ve Spradon hariç) Kayalıpınar değerine benzerlik gösterir. Yaşam beklentisi Kayalıpınar'da ilk bir yaş için yaklaşık 7 yıl, ilk beş yaş için ise 28,24 yıldır. Topluluk genelinde 15 yaş ile birlikte yaşam beklentisi 20 yllin altına inmektedir. Ayrıca erkeklerde kadınlara göre 2,35 yıl daha fazladır. Toplumda yaş artışı ile yaşam beklentisi arasında zıt bir ilişki vardır.

Kayalıpınar toplumu erişkinlerine bakılacak olursa, ölümler erkeklerde 35-40, kadınlarda ise 2025 yaş grubunda oransal olarak yüksektir. Genç erişkin kadınların bu yaş grubunda daha çok hayatını kaybetmesi doğum öncesi ve sonrasi meydana gelen komplikasyonlardan kaynaklı olabileceği düşünülebilir. (Başoğlu ve Şener, 2015; Çırak vd., 2019). Kayalıpınar'da
90 kadın bireyden 83'ünün yaşı veya yaș aralığı bilinmektedir. $18-25$ yaş aralı̆̆ında 21 birey, $18-30$ yaş aralığında ise 32 kadın birey yer alır. Bir bütün olarak bakıldığında genç erişkin kadınlar 83 kadının yaklaşık \%40'ina eşittir, bu ise önemli bir değer olarak kabul edilebilir. Sonuçları bağlamında kesin bir değerlendirme yapmaktan kaçınılsa da üzerinde durulması gereken bir sonuç olduğu söylenebilir.

Toplum erişkinlerinin daha çok orta erişkinler etrafında toplandığ1 saptanmıştır. Benzer bir durum Pinarkent Roma (Şahin vd., 2015), Parion Roma (Çırak vd., 2019), Cevizcioğlu Hellenistik-Roma (Erdal, 1999), Spradon Geç Roma-Erken Bizans (Çırak vd., 2018) ve Komana Ortaçağ (Erdal vd., 2015) dönemi erişkinleri için de söz konusudur. Yortanlı Geç Bizans’ta yetişkinlik ve olgunluk dönemindeki bireylerin nüfus içerisindeki oranı sirasiyla \%39,25 ve \%19,62'dir (Nalbantoğlu vd., 2000). Topaklı Erken Bizans'ta 15 yaş ve üzerindeki bireylerin ortalama yaşı 32,8 y1l olarak hesaplanmıştır (Güleç, 1988). Anadolu Ortaçağ topluluklarında, erişkinlerdeki ortalama yaşam süresi Değirmentepe için 34,4 (Özbek, 1986), Havuzdere için 35,27 (Özer vd., 2016) ve Minnetpınarı için 31,87 yıldır (Yiğit vd., 2008). Değirmentepe erişkinlerinin genç ya da orta yaşlarda yaşamlarını yitirdikleri, Havuzdere insanlarının ise genel olarak genç bir nüfusa sahip oldukları anlatılmaktadır. Elaiussa Sebaste'de (MS 6-7. yüzyıl/Bizans) ortalama yaş erkeklerde 38, kadınlarda 34 yıl olarak bulunmuştur (Paine vd., 2007). Bu sonuçlar Kayalıpınar verileri ile kısmen yakınlık gösterir.

Kayalıpınar topluluğunda oluşan demografik tablonun daha iyi anlaşılabilmesi için bireylerin ölümüne yol açan faktörlerin bilinmesi son derece önemlidir. Ancak şu ana kadar topluluk paleopatolojisine dair henüz bir çalışma bulunmamaktadır. Ancak ağız sağlığına ait sonuçlar, tarım toplumu özellikleri göstermektedir (yayına hazırlanıyor). Bununla birlikte iskeletlerin incelenmesi sırasinda bazı paleopatoloji örnekleri ile de karşılaşılmıştır. Bunlar arasında düzensiz kaynaşmış clavicula ve radius kırıklar1, cribra orbitalia, porotic hyperostosis, periostitis, osteomyelitis, osteomalasia, osteoporoz, sinüzit (?), eklem hastalıkları, rhomboid fossa, entosopati, erken sutur kaynaşması yer alır. Bu veriler topluluk hakkında bazı ipuçları vermekle birlikte, patoloji örneklerinin topluluk insanlarının yaşamlarını ne derece etkilediği detaylı bir inceleme ile anlam kazanabilecektir.

\section{Sonuç}

Genel olarak anlatılanlara bakıldığında, insan ve çevre kaynaklı tafonomik faktörlerin mezarlık alanı üzerinde olumsuz bir etki yarattığı, dolayısıyla toplumun demografik dağılımını etkilemiş olduğu aşikârdır. Bulguları itibariyle Kayalıpınar insanlarının birçok 
eski Anadolu topluluğu ile benzerlikleri olduğu kadar farklı yönleri de saptanmıştır. Sütten kesme süreci ve ek besinlerin alınmaya başlandığı dönemin yarattığ1 olumsuzluklar, 2-5 yaş arasındaki bireylerin çevre ile iç içe olması ve bağımsız olarak hareket edebilmesinin çıkardığı sorunlar toplumu olumsuz yönde etkilemiştir. Ayrıca gözlenen paleopatoloji örnekleri, toplumun bir bölümünde sağlik durumunun çok da iyi olmadığının kanıtıdır. Bu bulgular toplumdaki yaşam beklentisinin düşmesine neden olmuş, ömür uzunluğunu doğrudan veya dolaylı olarak etkilemiştir. İlerleyen y1llarda iskelet sayısının da artmasıyla toplum insanlarının demografik yapısı hakkında daha güvenilir değerlendirmeler yapılabilecektir. Aynı zamanda Kayalıpınar iskelet topluluğunun paleopatolojik açıdan yakın zamanda incelenecek olması, ölümlere yol açan etkenler başta olmak üzere birçok soruya yanıt getirecektir. Bunun sonucunda da toplumun sosyo-ekonomik yapisı daha sağlıklı bir şekilde ortaya çıkmış olacaktır.

\section{Kaynakça}

Akbulut, G. (2009). Sivas Şehri'nin tarihi coğrafyası. C.Ü. FenEdebiyat Fakültesi Sosyal Bilimler Dergisi, 33(2), 212-222.

Alpagut, B., ve Erdoğan, N. (2016). Mardin-Dara Geç Roma dönemi iskelet toplumunun demografik analizi. Arkeometri Sonuclar Toplantısı, 31, 291-300. https://kvmgm.ktb.gov.tr/ Eklenti/45226,31arkeometri.pdf?0

Atamtürk, D., ve Duyar, İ. (2008). Adramytteion (Örentepe) iskeletlerinde ağız ve diş sağlığı. H.Ü. Edebiyat Fakültesi Dergisi, 25(1), 1-15.

Başoğlu, O., ve Şener, T. (2015). Ovaören Erken Tunç Çağı insanları: Antropolojik bir inceleme. Hitit Üniversitesi Sosyal Bilimler Enstitüsü Dergisi, 8(2), 455-476. https://doi.org/10.17218/ husbed.15692

Brothwell, D. R. (1981). Digging up bones: Excavations, treatment and study of buman skeletal remains (3. Basim). Oxford University Press.

Buikstra, J. E., ve Ubelaker, D. H. (1994). Standards for data collection from buman skeletal remains. Arkansas Archaeological Survey Research Series, No: 44.

Büyükkarakaya, A. M. (2017). Tepecik-Çiftlik Neolitik topluluğunun demografik özellikleri. Folklor ve Edebiyat, 23(92), 79-98. https://doi.org/10.22559/folkloredebiyat.2017.57

Büyükkarakaya, A. M., Alpagut, A., Çubukçu, E., ve Cavalli, F. (2018). Juliopolis (Iuliopolis) antropolojik araştırmaları: İlk çalışmalar. Ankara Araştırmalan Dergisi, 6(2), 111-126. https:// doi.org/10.5505/jas.2018.43433

Cahen, C. (2000). Osmanlulardan önce Anadolu (La Turquie pré-ottomane). Tarih Vakfi Yurt Yayınları.

Ç1rak, A. (2009). Kelenderis iskeletlerinin paleoantropolojik analizi ve Anadolu toplumlar arasindaki yeri. Yayımlanmamıs Doktora Tezi. Ankara Üniversitesi Sosyal Bilimler Enstitüsü, Ankara.

Çırak, M. T. (2017). Akgüney Geç Roma-Bizans dönemi toplumu üzerine paleodemografik çalışma. Hitit Üniversitesi Sosyal Bilimler Enstitüsü Dergisi, 10(1), 249-263. https://doi.org/10.17218/ hititsosbil.313652

Çırak, M. T., Çırak, A., ve Şarbak, A. (2018). Antik Spradon toplumunun paleodemografik yapısı. T. Erdoğan (Ed.) içinde, Current academic studies in social sciences 2018 (s. 21-35). Gece Kitaplığ1.

Çırak, M. T., Keleş, V., Şarbak, A., ve Acar, E. (2019). Parion oda mezar 5 iskeletlerinin paleodemografik yap1sı. B. C. Ataman ve G. Taşkıran (Ed.) içinde, Recent evaluations on bumanities \& social sciences (s. 127-142). IJOPEC Publication Limited.

Demirel, F. A. (2013). Amorium aşağı şehir kilisesi bebek ve çocuk iskeletleri. A. Ü. DTCF Dergisi, 53(1), 349-364. https://doi. org/10.1501/Dtcfder 0000001334

Demirel, F. A. (2017). Human remains. P. Niewöhner (Ed.) içinde, The archaeology of Byzantine Anatolia: From the end of late antiquity until the coming of the Turks (s. 60-70). Oxford University Press. https://doi.org/10.1093/ acprof:oso/9780190610463.003.0005

DeWitte, S. N. (2018). Demographic anthropology. American Journal of Physical Anthropology, 165(4), 893-903. https://doi. org/10.1002/ajpa.23317

Erdal, Ö. D. (1997). Demre Aziz Nikolaos kilisesinden çıkarılan insan iskeletlerinin antropolojik açdan incelenmesi. Yayımlanmamıs Yüksek Lisans Tezi. Hacettepe Üniversitesi Sosyal Bilimler Enstitüsü, Ankara.

Erdal, Ö. D., Eroğlu, S., Erdal, Y. S., ve Büyükkarakaya, A. (2003). Şaşal/İzmir iskelet topluluğunun paleopatolojik ve demografik analizi. Arkeometri Sonuclar Toplantısı, 18, 1-14. http://www. kulturvarliklari.gov.tr/sempozyum pdf/arkeometri/18 arkeometri.pdf

Erdal, Y. S. (1996). İznik Geç Bizans dönemi insanlarmın çene ve dişlerinin antropolojik açıdan incelenmesi. Yayımlanmamış Doktora Tezi. Hacettepe Üniversitesi Sosyal Bilimler Enstitüsü, Ankara.

Erdal, Y. S. (1999). İnsan iskelet kalıntılarının antropolojik açıdan incelenmesi. T. Özkan ve H. Erkanal (Ed.) içinde, Tabtalı Barajı Kurtarma Kazısı Projesi. Kültür ve Turizm Bakanlığı Yayınları.

Erdal, Y. S. (2000). Eski Anadolu toplumlarında çocuk sağlığ1 ve hastalıkları. Cocuk Sağhlğ ve Hastahklar Dergisi, 43, 5-19.

Erdal, Y. S. (2010). Oluz Höyük kazılarından ele geçen insan iskeletlerine ait antropolojik araştırmanın ilk sonuçları. Ş. Dönmez (Ed.) içinde, Kăsku Ülkesi'nin önemli kenti AmasyaOluz Höyük: 2007 ve 2008 dönemi çalssmalar genel değerlendirmeler ve ön sonuclar (s. 111-120). T.C. Amasya Valiliği Yayın No: 48.

Erdal, Y. S. (2013). Life and death at Hakemi Use. O. Nieuwenhuyse, R. Bernbeck, J. Rogasch ve P. Akkermans (Ed.) içinde, Interpreting the Late Neolithic of Upper Mesopotamia. Brepols Publishers.

Erdal, Y. S., Erdal, Ö. D., ve Koruyucu, M. M. (2015). Ortaçağ'da nüfus değişimi öncesine ait bir Bizans topluluğu: Komana insan kalıntılarının antropolojik analizi. D. B. Erciyas ve M. N. Tatbul (Ed.) içinde, Komana Ortaçağyerleşimi (s. 83-114). Ege Yayınları.

Erkman, A. C. (2008). Van Dilkaya Erken Demir Că̆ ve Ortaçăg 
toplumunda ăğz ve dişs sağhl̆ğ. Yayımlanmamış Doktora Tezi. Ankara Üniversitesi Sosyal Bilimler Enstitüsü, Ankara.

Goodman, A. H., ve Rose, J. C. (1990). Assessment of systemic physiological perturbations from dental enamel hypoplasias and associated histological structures. American Journal of Physical Anthropology, 33(S11), 59-110. https://doi. org/10.1002/ajpa.1330330506

Gözlük, P. (2004). Van-Karagündüz populasyonunun dişlerinin ve çenelerinin paleopatolojike açıdan incelenmesi. Yayımlanmamış Doktora Tezi. Ankara Üniversitesi Sosyal Bilimler Enstitüsü, Ankara.

Gözlük Kırmızıoğlu, P., ve Sevim Erol, A. (2017). The skeletons of Saint Mercurius (Aziz Mercurius iskeletleri). Social Sciences Studies Journal, 3(6), 859-872. https://doi.org/10.26449/ $\underline{\text { sssj. } 105}$

Güleç, E. (1988). Topaklı populasyonunun demografik ve paleoantropolojik analizi. Araștırma Sonuclar Toplantısı, 5(2), 347-357. http://www.kulturvarliklari.gov.tr/sempozyum pdf/arastirmalar/05 arastirma 2.pdf

Gümüş, B., Topal, İ., Özer, Ö., ve Balandız, H. (2018). Türkiye’de 15 yaş altı çocuk ölümlerinin değerlendirilmesi. Furat Üniversitesi Sağllk Bilimleri Tap Dergisi, 32(1), 13-19.

Hoppa, R. D. (2002). Paleodemography: Looking back and thinking ahead. R. D. Hoppa ve J. W. Vaupel (Ed.) içinde, Paleodemography: Age distributions from skeletal samples (s. 9-28). Cambridge University Press. https://doi.org/10.1017/ CBO9780511542428.002

Karaöz Arıhan, S., ve Acar, E. (2015). Giresun Adası iskeletlerinin paleoantropolojik değerlendirmesi. Arkeometri Sonuclar Toplantısi, 30, 189-202. $\quad$ https://kvmgm.ktb.gov.tr/ Eklenti/43558,30arkeometri.pdf?1

Kaur, H., ve Jit, I. (1990). Age estimation from cortical index of the human clavicle in northwest Indians. American Journal of Physical Anthropology, 83(3), 297-305. https://doi.org/10.1002/ ajpa.1330830304

Koca Özer, B., Gültekin, T., Özer, İ., Sağır, M., ve Güleç, E. (2008). Longevity in ancient Anatolian and turkish populations from Neolithic to present. E. B. Bodzsar and C. Susanne (Ed.) içinde, Ageing related problems in past and present populations Biennial books of EAA, 5 (s. 45-58).

Koca Özer, B., Sağır, M., Özer, İ., ve Güleç, E., (2014). Anadolu Ortaçağı'nda insan sağlı̆̆ı. Ç. Aşkit, S. Kalaycıŏ̆ulları, R. Kayapınar, R. Öztürk ve C. Üstünel Keyinci (Ed.) içinde, In memoriam Filiz Öktem (s. 147-154). Ankara Üniversitesi Yayınları.

Koruyucu, M. M. (2012). Köşk Höyük Ortaçăg insanlarmmn antropolojile. analiz̨i. Yayımlanmamış Yüksek Lisans Tezi. Hacettepe Üniversitesi Sosyal Bilimler Enstitüsü, Ankara.

Lovejoy, C. O., Meindl, R. S., Pryzbeck, T. R., ve Mensforth, R. P. (1985). Chronological metamorphosis of the auricular surface of the ilium: A new method for the determination of adult skeletal age at death. American Journal of Physical Anthropology, 68(1), 15-28. https://doi.org/10.1002/ajpa.1330680103

Müller-Karpe, A. (2006). Untersuchungen in Kayalıpınar 2005.
Mitteilungen der Deutschen Orient-Gesellschaft, 138, 211-247.

Müller-Karpe, A., ve Müller-Karpe, V. (2006). Kız1lırmak (Maraşanta) kıyısındaki bir Hitit kentinde yeni araştırmalar. Arkeoloji ve Sanat Dergisi, 123, 1-12.

Müller-Karpe, A., ve Müller-Karpe, V. (2009). Untersuchungen in Kayalipinar und Umgebung 2006-2009. Mitteilungen der Deutschen Orient-Gesellschaft, 141, 173-238.

Müller-Karpe, V., ve Müller-Karpe, A. (2012). Kayalıpınar'da yapılan araştırmalar. Araştırma Sonuçlar Toplantısı, 29(2), 407418. https://kvmgm.ktb.gov.tr/Eklenti/4649,29arastirma2. pdf?0

Nalbantoğlu, E., Türk, H., ve Nalbantoğlu, C. (2000). 1996 y1lı Yortanlı nekropolis kazısı iskelet populasyonu üzerinde paleoantropolojik çalışmalar. Türk Arkeoloji ve Etnografya Dergisi, 1, 27-36.

Olivier, G. (1969). Practical anthropology. Charles C. Thomas Publisher.

Ökmen, M. (2001). Sivas'ta kentsel gelişme. C.Ü. İktisadi ve İdari Bilimler Dergisi, 2(1), 239-264.

Ökse, A. T. (1994). Sivas İli 1992 yüzey araştırması. Araştırma Sonuclar Toplantısı, 11, 243-258. http://www.kulturvarliklari. gov.tr/sempozyum pdf/arastirmalar/11 arastirma.pdf

Ökse, A. T. (1999). Sivas İli 1997 yüzey araştırması. Araştırma Sonuclar Toplantısı, 16(1), 467-490. http:/ / www.kulturvarliklari. gov.tr/sempozyum pdf/arastirmalar/16 arastirma 1.pdf

Özbek, M., ve Erdal, Ö. D. (2006). Anadolu'nun bazı Neolitik ve Kalkolitik topluluklarında bebek ölümleri ve olası nedenleri. Türk Arkeoloji Dergisi, 6, 41-52.

Özer, İ., ve Sağır, M. (2003). Dilkaya ve bazı eski Anadolu toplumlarında uzun kemiklerin çevre ölçülerinden cinsiyet tayini. Antropoloji, 16, 87-98.

Özer, İ., Sağır, M., Koca Özer, B., Karatufan, A., ve Şahin, S. (2016). Havuzdere Ortaçağ iskeletlerinin paleoantropolojik analizi. $A$. Ü. Sosyal Bilimler Dergisi, 2, 47-57. https://doi.org/10.1501/ sbeder 0000000123

Paine, R. R., Vargiu, R., Coppa, A., Morselli, C., ve Schneider, E. E. (2007). A health assessment of high status Christian burials recovered from the Roman-Byzantine archaeological site of Elaiussa Sebaste, Turkey. HOMO, 58, 173-190. https://doi. org/10.1016/j.jchb.2006.06.001

Sağır, M., Özer, İ., Satar, Z., ve Güleç, E. (2004). Börükçü iskeletlerinin paleoantropolojik incelenmesi. Arkeometri Sonuclar Toplantısı, 19, 27-40. http:/ / www.kulturvarliklari.gov. tr/sempozyum pdf/arkeometri/19 arkeometri.pdf

Sağır, S. (2013). Dişlerin çıkıs ve gelişim aşamalarndan yaş tahmini metodu oluşturulması. Yayımlanmamış Doktora Tezi. Ankara Üniversitesi Sosyal Bilimler Enstitüsü, Ankara.

Szilvàssy, J., ve Kritscher, H. (1990). Estimation of chronological age in man based on the spongy structure of long bones. Anthropologischer Anzeiger, 48(3), 289-298.

Şahin, S., Özbulut, Z., Özer, İ., Sağır, M., ve Güleç, E. (2015). Pınarkent Roma dönemi iskeletlerinin paleoantropolojik analizi. A.Ü. Sosyal Bilimler Dergisi, 6(1), 57-70. https://doi. org $/ 10.1501 /$ sbeder 0000000091 
Tritsaroli, P., ve Karadima, C. (2017). The people of Early Byzantine Maroneia, Greece (5th-6th c. AD). Bioarchaeology of the Near East, 11, 29-62.

Ubelaker, D. H. (1989). Human skeletal remains: Excavations, analysis, interpretation. Smithsonian Institution.

Üstündağ, H. (2009). Kuşadası Kadıkalesi/Anaia kazısında bulunan insan iskelet kalıntıları. Arkeometri Sonuclar Toplantısı, 24, 209228. http://www.kulturvarliklari.gov.tr/sempozyum pdf/ arkeometri/24 arkeometri.pdf

Üstündağ, H., ve Demirel, F. A. (2009). Alanya Kalesi iskelet topluluğunda ağız ve diş sağlığı. H. Ü. Edebiyat Fakültesi Dergisi, 26(1), 219-234.

Workshop of European Anthropologists (WEA) (1980). Recommendations for age and sex diagnoses of skeletons. Journal of Human Evolution, 9(7), 517-549. https://doi. org/10.1016/0047-2484(80)90061-5

Yaşar, Z. F. (2007). Adli dental antropoloji: Dental antropoloji açısindan Minnetpınar ve Güllüdere toplumlarmnn dişlerinin karşılasstırmal analiz̧. Yayımlanmamıs Doktora Tezi. Ankara Üniversitesi Sosyal Bilimler Enstitüsü, Ankara.

Yiğit, A., Gözlük Kırmızıŏlu, P., Durgunlu, Ö., Özdemir, S., ve Erol, A. S. (2008). Kahramanmaraş/ Minnetpınarı iskeletlerinin paleoantropolojik açıdan değerlendirilmesi. Arkeometri Sonuclar Toplantısı, 23, 91-110. http://www.kulturvarliklari. gov.tr/sempozyum pdf/arkeometri/23 arkeometri.pdf

\section{Çevrimiçi Kaynakça}

https://earth.google.com/web/search/Kayal\%c4\%b1p \%c4\%b1 nar, + Y $\%$ c4\%b1ld $\%$ c4\%b1zeli $\% 2$ fSivas, + T $\%$ c 3\%bcrk iye/@39.61803207,36.52853545,1216.48162617a,920. 29754785d,35y,264.64552264h,0t,0r/data=CigiJgokCcCpy09Q1UNAER Ci8ePykNAGcZe0F6rQkJAIc7uHG8rOUIA (Erişim Tarihi: 11.05.2020)

\section{(c) (1) (8) \\ BY NC 2020. Telif haklar1 yazar(lar)a aittir.}

Bu makale Creative Commons Atıf-GayriTicari 4.0 Uluslararas1 (CC BY-NC 4.0) lisansının hüküm ve şartları altında yayımlanan açık erişimli bir makaledir. 